\title{
Dietary fibres and associated compounds in rape seed and biorefined rape seed products compared to DF in pea*
}

\author{
Charlotte Bjergegaard, H. Sørensen and Susanne Sørensen
}

\author{
Chemistry Department, Roval Veterinary and Agricultural University \\ 40, Thorvaldsensvej, DK-1871 Frederiksberg C, Denmark
}

(Received 25 April 1997; accepted 15 May 1997)

\begin{abstract}
Dietary fibres (DF) - their chemical composition and structure, physico-chemical properties, and physiological effects - comprisc and arca of increasing scientific interest. Progress in this rescarch is, however, rendered somewhat difficult by the disagreement concerning demarcation of the DF concept. In the present study, a physiological based method of analysis for determination of total DF (TDF) corresponding to the sum of insoluble DF (IDF) and soluble DF (SDF) have been used as an initial step in studies of DF from different rape seed varieties and biorefined fractions of double low rape seed compared to DF from peas.

A comprehensive characterization of DF from rape seed and peas have been performed, with determination of the neutral monosaccharide composition by different techniques as a first step. The yield of sugars, especially glucose, was found highly dependent on the procedure used for hydrolysis of the polysaccharides. The composition of the polysaccharide fractions also differed according to the type of plant material. This diversity was further emphasised by results from sequential extraction and separation of isolated DF leading to fractionation of $\mathrm{DF}$ into four groups: pectins, hemicelluloses, celluloses, and lignins. UV-VIS-spectroscopy of cxtracts from these groups provided useful information concerning the presence of material of non-carbohydrate origin. The hemicellulose fractions from peas and especially rape seed were shown to have the highest content of proteins and phenolics, possibly being present as strongly adsorbed or covalently bound components. The protein part of the DF fractions was further investigated by biochemical methods of analyses including affinity chromatography, electrophoresis as SDS IEF, and the presence of myrosinases was demonstrated in DF from rape seed. Pcas also comprised DF associated proteins, although the level was considerable lower than found in rape seed DF. High performance capillary electrophoresis methods for determination of phenolics have been developed in order to provide an efficient tool for
\end{abstract}

\footnotetext{
* Part of this paper was presented at the Symposium: Dietary fibre - chemical composition and biological action, 24-25 April 1997, Radzików, Poland
} 
characterization of the phenolic DF components. Application of the above mentioned methods to studies of DF and fractions of DF have demonstrated the presence of apprcciablc amounts of protcin and various types of low molecular weight compounds, especially phenolics, associated to DF.

KEY WORDS: dictary fibres, rape seed, pea

\section{INTRODUCTION}

Dietary fibres (Asp et al., 1988) are dominated by non starch polysaccharides (NSP) and polyphenolic lignin, but other indigestible components are found in close association with the NSP constituents, e.g. cell wall proteins and phenolic carboxylic acid derivatives, oligosaccharides of the raffinose family and tannins. In addition, resistant starch may also be included in the group of dietary fibre components (Asp et al., 1987). The proteins and the phenolic carboxylic acid derivatives are most important and are present in the largest amounts.

The development of gravimetric methods of analyses of dietary fibres (DF) had its beginning in the second half of the nineteenth century, with the introduction of the crude fibre or Weende method. This method implied extraction by dilute acid and alkali with subsequent isolation of the insoluble residue by filtration (Prosky and DeVries, 1992a, b). The residue contained only a minor and varying part of the DF fraction with the more soluble components being totally lost. This loss was also the shortcoming of the acid detergent fibre (ADF) and neutral detergent fibre (NDF) methods (Van Soest, 1963; Van Soest and Wine, 1967), however, the milder extraction conditions resulted in higher and more stable yields of the insoluble part of DF compared to the crude fibre method. The analytical approach of later developed gravimetric methods, using enzymes in combination with chemicals for extraction, comprised recovering of both insoluble (IDF) and soluble dietary fibres (SDF) (Asp et al., 1983). These methods have, on the other hand, been criticized for overestimation of the DF content by including components in the residue different from the traditional DF components, e.g. cell wall proteins, Maillard reaction products, tannins, low molecular weight (LMW) phenolic acid derivatives, saponins etc. Correction for protein and ash in DF is a common feature for many of the methods, however, the actual calculation procedure may vary, and various proteins are in fact constituents of plant cell walls and thereby of DF (Bjergegaard et al., 1997a).

The method used for TDF (IDF+SDF) in this work is the enzymatic gravimetric method, slightly modified from Asp et al. (1983). Moreover, a modification of the experimental procedure (dialysis) has been introduced in order to diminish the problems caused by ash in the SDF residues, and the DF have furthermore been investigated for compounds associated to the DF 
fractions: pectins, hemicellulose, cellulose and lignin. The presence of these DF associated components has a great influence on the properties of DF, and it is therefore necessary to include these fibre associated compounds in the analysis and characterisation of DF for understanding of the properties DF have. The physico-chemical properties of DF include, among other, the ability of DF to hold water and to bind organic molecules, macro nutrients, micronutrients, xenobiotics and minerals (Bjergegaard et al., 1997a).

\section{MATERIAL AND METHODS}

\section{Plant material}

Seeds of double low winter rape and spring rape (Brassica napus L.) were obtained from Danish Plant breeding, St. Heddinge, Denmark cv. Ceres (CER), cv. Librador (LIB), (LIB1), cv. Bingo (BIN1), all yellow flowered, brown seeded rape seed), Maribo Frø, Holeby, Denmark (MRSW, white flowered, yellow seeded rape seed), and Trifolium Roskilde, Denmark (MRS and NRS; yellow flowered, brown seeded rape seed). Biorefining of NRS rape seed was performed by aqueous enzyme based processing resulting in: PRM (Protein rich meal), LIPRO (liproprotein) and rape seed hulls (NRH). This procedure has been described elsewhere (Olsen, 1988; Jensen et al., 1990; Bagger et al., 1996). Seeds of peas (Pisum sativum L.) were obtained from Danish Plant Breeding St. Heddinge, and from Pajbjergfonden, Dyngby, Odder, Denmark (cv. Bohatyr $(\mathrm{BOH})$, cv. Solara (SOL), cv. Kelwo (KEL)). Grindsted Nutrio, Haderslev (Denmark) contributed with pea hulls (PHU). The samples were selected to represent rape seed, peas, as well as different fractions hereof, with appreciable variations in DF levels.

\section{Chemicals and enzymes}

All chemicals were of analytical-reagent grade. Water was double deionized. The enzymes used comprised a heat resistant $\alpha$-amylase (Termamyl, $120 \mathrm{~L}$; Novo Nordisk A/S, Copenhagen, Denmark), pepsin (2000 FIP-U/g, Cat. no. 7190, Merck, Darmstadt, Germany), and pancreatin (4 x U.S.P., Cat. no P-1750; Sigma, Montana, USA).

Analysis of dietary fibres

Development of an AOAC method (Association of Official Analytical Chemists) for determination of total dietary fibres (Prosky et al., 1984, 1985) has 
been based primarily on the experience of three scientific groups (Schweizer and Würsch, 1979; Furda, 1981; Asp et al., 1983). In these methods, TDF were further divided into IDF and SDF, and in 1988, the AOAC method for determination of TDF was suggested correspondingly extended (Prosky et al., 1988). The principles of analysis comprise in all methods enzymatic treatments of the sample followed by filtration or centrifugation to obtain the insoluble residue. The soluble residue is then isolated (filtration/centrifugation) from the filtrate or supernatant by precipitation with ethanol. A preliminary chemical extraction of fat from the sample is common in all methods, whenever the fat content exceeds $5-10 \%$. This extraction can now be performed as a fast and simple SFE procedure (Buskov et al., 1997).

Conspicuous is the total time of incubation with enzymes, which has been reduced from $38 \mathrm{~h}$ to $1.25 \mathrm{~h}$ (Table 1). High efficiency of the starch and protein digestion with short incubation times was verified by Asp et al. (1983), using Termamyl, pepsin and pancreatin and a total incubation time of $2.25 \mathrm{~h}$. Termamyl, a heal-stable $\alpha$-amylase free of any contaminating $\beta$-glycosidase activities, is working in the starch gelatinization step, avoiding retrogradation of solubilized starch when cooling the samples (Theander, 1983). Resistant starch (RS) is not degraded by Termamyl, and will contribute to the DF value (Asp, 1990).

The enzymatic gravimetric analysis used followed the principles described by Asp et al. (1983). The present study comprised two methods where the analytical procedure in method II comprised some extra modifications. All samples were run in duplicate, and a blank (no sample, only reagents) were included for every new series of analyses.

TABLE 1 Overview of selected steps in enzymatic gravimetric methods used for determination of DF (TF, IDF, SDF). The parenthesis in the incubation media column state whether $\mathrm{HCl}$ or $\mathrm{NaOH}$ have been used for regulation of $\mathrm{pH}$

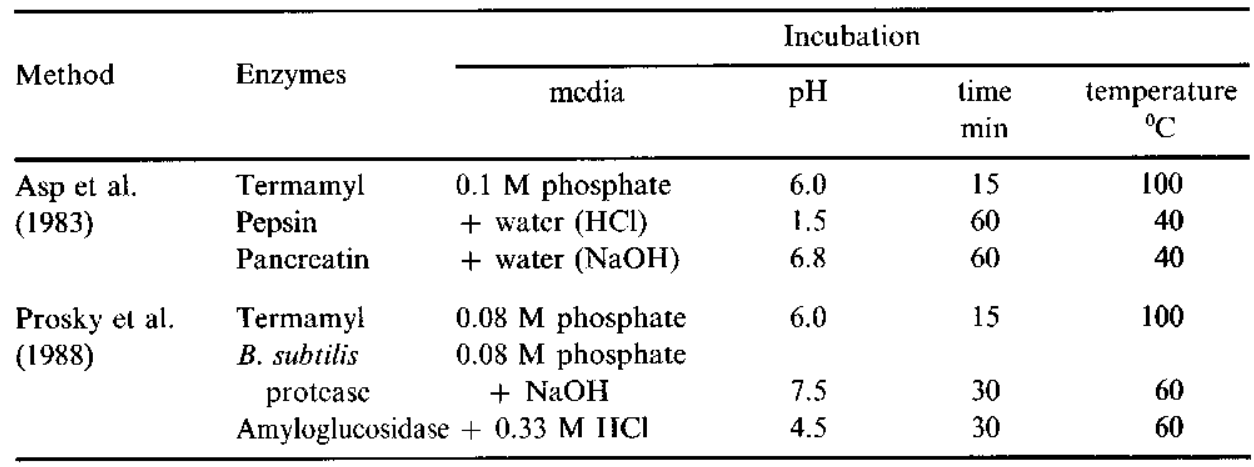


Analysis of DF; Method I

Seeds were milled in a laboratory mill, whereas PRM and PHU were milled at the place of production. Moisture content was determined by drying to constant weight $\left(3 \mathrm{~h}\right.$ at $\left.105^{\circ} \mathrm{C}\right)$.

Fat extracted, milled seeds $(0.5 \mathrm{~g})$ were weighed into $100 \mathrm{ml}$ Erlenmeyer flasks with magnet and thoroughly suspended in sodium phosphate buffer $(25 \mathrm{ml}, 0.1$ M, pH 6.0). Termamyl $(100 \mu \mathrm{l})$ was added and the covered flasks were placed in a boiling water bath for $30 \mathrm{~min}$. The samples were mixed manually at $5 \mathrm{~min}$ intervals. $\mathrm{HCl}(20 \mathrm{ml}, 0.2 \mathrm{M})$ was added after cooling to room temperature, and $\mathrm{pH}$ was adjusted to 1.5 with $\mathrm{HCl}(1.0 \mathrm{M})$ or $\mathrm{NaOH}(1.0 \mathrm{M})$. Pepsin $(100 \mathrm{mg})$ was added and the samples were incubated in water bath with shaker $\left(60 \mathrm{~min} ; 40^{\circ} \mathrm{C}\right)$. Magnetic stirring of the samples was performed after $30 \mathrm{~min}$. $\mathrm{NaOH}(10 \mathrm{ml}, 0.55$ M) and sodium phosphate $(10 \mathrm{ml}, 0.2 \mathrm{M}, \mathrm{pH} 6.8)$ were added and $\mathrm{pH}$ was adjusted to 6.8 with $1.0 \mathrm{M} \mathrm{HCl}$ or $1.0 \mathrm{M} \mathrm{NaOH}$. Pancreatin $(100 \mathrm{mg})$ was added and the samples were incubated in water bath with shaker $\left(60 \mathrm{~min} ; 40^{\circ} \mathrm{C}\right)$. Magnetic stirring of the samples was performed after $30 \mathrm{~min}$. $\mathrm{CH}_{3} \mathrm{COOH}(5 \mathrm{ml}$, $0.94 \mathrm{M}$ ) was added and $\mathrm{pH}$ was adjusted to $4.5 \pm 0.1$ with $1.0 \mathrm{M} \mathrm{HCl}$.

IDF was isolated by filtration on a filter crucible (porosity $40-100 \mu \mathrm{m}$ ) with celite $(0.5 \mathrm{~g})$, and the residue (IDF) was washed with $2 \times 10 \mathrm{ml}$ water. Filtrates and water washing were saved for determination of SDF. The IDF residues were further washed with $2 \times 10 \mathrm{ml} 96 \%$ ethanol and $2 \times 10 \mathrm{ml}$ acetone, and the residues were dried and weighed.

SDF was precipitated from the filtrate+water washing with ethanol (4 volumes of $96 \%$ ethanol, $600^{\circ} \mathrm{C}, 60 \mathrm{~min}$ ) before the precipitate was isolated by filtration (wash with $2 \times 10 \mathrm{ml} 80 \%$ ethanol; $2 \times 10 \mathrm{ml} \mathrm{96 \%}$ ethanol; $2 \times 10 \mathrm{ml}$ acetone) or centrifugation, dried and weighed.

Analysis of DF; Method II

The analytical procedure was identical to that of method I to the point where filtration start. The changes in the filtration procedure include omission of celite from the crucibles used for filtration of IDF. With respect to SDF, the precipitation step was replaced by overnight dialysis (cut-off-value for dialysis bags: $12000-14000 \mathrm{~g} / \mathrm{mol}$ ) of the combined filtrate, followed by freeze drying. $\mathrm{N}$ and ash analyses were performed on the weighed residues. $\mathrm{N}$ and ash analyses on blank samples within the different methods followed the principles for the actual method described above. 
Analyses of $N$ and ash

The content of $\mathrm{N}$ was determined according to the Dumas principle, with $\mathrm{N}$-oxides, produced by combustion at high temperature (about $1000^{\circ} \mathrm{C}$ ) in an oxygen atmosphere, being reduced to $\mathrm{N}_{2}$ by the passage of a copper-containing column. $\mathrm{N}_{2}$ was detected in a thermal conductivity cell and the factor 6.25 was used for calculation of corresponding protein content. The apparatus used was a Carlo Erba NA 1500 Automatic Nitrogen Analyzer. Ash was determined according to the standard method (AOAC, 1965).

\section{Fractionation of dietary fibres}

The fractionation scheme used in the present study divided the isolated DF into four fractions named pectic material (PEC), hemicelluloses (HEM), cellulose (CEL), and lignins (LIG). The fraction names refer to the actual extraction conditions.

(A) PEC: Extraction of pectic polysaccharides may be performed in several ways including use of hot water, cold water and hot or cold aqueous solutions of different chelating agents (Selvendran et al., 1985; Fry, 1988).

PEC was obtained as the supernatant after extraction of IDF or SDF $(1 \mathrm{~g})$ with water $(25 \mathrm{ml})$ for $2 \mathrm{~h}$ at $70^{\circ} \mathrm{C}$ in a shaking waterbath. The sediment remaining after cooling and centrifugation $(34000 \mathrm{x} \mathrm{g} ; 20 \mathrm{~min})$ was freeze dried, weighed, and used in (B). A fraction of supernatant $(5 \mathrm{ml})$ was kept at $-20^{\circ} \mathrm{C}$ for further analyses. The rest (known volume) was dialysed against water overnight $\left(5^{\circ} \mathrm{C}\right)$ and another $5 \mathrm{ml}$ was saved $\left(-20^{\circ} \mathrm{C}\right)$. The remaining dialysed supernatant (known volume) was freeze dried, weighed, and saved in desiccator.

(B) HEM: Hemicelluloses comprise polysaccharides obtained by selective extraction with aqueous alkali after the water soluble pectic substances have been removed (Dreher, 1987). The extraction can be performed with a range of alkali strengths, and hemicellulose $\mathrm{A}, \mathrm{B}$, and $\mathrm{C}$ are examples of different subfractions of hemicelluloses. Hemicellulose $A$ appears as a precipitate, when neutralizing or slightly acidifying the base extract (weak alkali) with acetic acid, and hemicellulose $\mathrm{B}$ is obtained when adding ethanol to $70-80 \%$ in the $\mathrm{pH}$ adjusted extract. Hemicellulose $\mathrm{C}$ is extracted by use of strong alkali (Dreher, 1987; Brett and Waldron, 1990; Southgate, 1991).

HEM was obtained as the supernatant after extraction of the sediment from (A) with $2.0 \mathrm{M} \mathrm{NaOH}(25 \mathrm{ml})$ under $\mathrm{N}_{2}$ for $2 \mathrm{~h}$ in a boiling waterbath with occasional shaking. The sediment remaining after cooling and centrifugation ( $34000 \mathrm{x} \mathrm{g} ; 20 \mathrm{~min}$ ) was freeze dried, weighed, and used in (C). The supernatant was made weakly acidic (3-4 $\mathrm{ml}$ acetic acid), and $5 \mathrm{ml}$ of the $\mathrm{pH}$ adjusted supernatant was kept at $-20^{\circ} \mathrm{C}$ for further analyses. The supernatant (known 
volume), was dialysed overnight $\left(5^{\circ} \mathrm{C}\right)$. Sedimented material was collected by centrifugation ( $3000 \mathrm{x} \mathrm{g} ; 3 \mathrm{~min})$, freeze dried, weighed, and kept in desiccator. The dialysed supernatant $(5 \mathrm{ml})$ was kept at $-20^{\circ} \mathrm{C}$ for further analyses. The remaining dialysed supernatant (known volume) was freeze dried, weighed and kept in desiccator.

(C) CEL was obtained as the supernatant after dissolving the sediment from (B) in $12.0 \mathrm{M} \mathrm{H}_{2} \mathrm{SO}_{4}\left(1 \mathrm{ml}, 35^{\circ} \mathrm{C}\right)$ under occasional mixing. After $1 \mathrm{~h}$, the mixture was diluted with $11 \mathrm{ml} \mathrm{H}_{2} \mathrm{O}$ to give a $1.0 \mathrm{M} \mathrm{H}_{2} \mathrm{SO}_{4}$ solution, and continued extraction and hydrolysis were performed in a boiling waterbath under reflux for $18 \mathrm{~h}$. The sediment remaining after cooling and centrifugation (table centrifuge; $3000 \times \mathrm{g} ; 3 \mathrm{~min}$ ) was freeze dried, weighed, and kept in desiccator (D). The supernatant (known volume) was neutralized with saturated $\mathrm{Ba}(\mathrm{OH})_{2}$ and centrifuged to remove $\mathrm{BaSO}_{4}$. Neutralized supernatant $(5 \mathrm{ml})$ was kept at $-20^{\circ} \mathrm{C}$ for further analyses, and the rest (known volume) was freeze dried, weighed, and kept in desiccator.

(D) LIG was obtained as the residue after acid extraction as described under (C). LIG is identical to Klason lignin.

The dialysis described was performed by use of dialysis bags with a cut-offvalue ranging from $12000-14000 \mathrm{~g} / \mathrm{mol}$. The colour of the different supernatants was noted prior to freeze drying.

\section{Thymol-sulphuric acid analysis of fractionated material}

The content of total carbohydrates (expressed as glucose) was determined for the PEC and HEM supernatants after dialysis and for the neutralized nondialysed CEL supernatant by the thymol-sulphuric acid method.

For samples of isolated DF 2-3 mg (known weight) were mixed with $\mathrm{H}_{2} \mathrm{SO}_{4}$ ( $1 \mathrm{ml} ; 77 \%$ ), and allowed to stand for $10 \mathrm{~min}$ with occasional mixing. Water $(4 \mathrm{ml})$ was then added carefully. After $5 \mathrm{~min}, 100 \mu \mathrm{l}$ of this solution was transferred to acid washed test tubes $\left(\mathrm{H}_{2} \mathrm{SO}_{4}\right)$ together with $400 \mu \mathrm{l}$ water, $50 \mu 1 \mathrm{l} \%$ thymol solution (ethanol basis), and $3500 \mu \mathrm{l} 77 \% \mathrm{H}_{2} \mathrm{SO}_{4}$. In the reference sample, $100 \mu \mathrm{l}$ probe was replaced by $100 \mu \mathrm{l}$ water. A standard curve was prepared from a glucose stock solution $(0.1 \mathrm{mg}$ glucose $/ \mathrm{ml})$. The mixtures were placed covered in a boiling waterbath for $35 \mathrm{~min}$, with mixing after 10 and $20 \mathrm{~min}$. Samples were cooled for $10 \mathrm{~min}$. The absorbance (undiluted samples) was measured in quartz cuvettes at $505 \mathrm{~nm}$.

\section{Hydrolysis of polysaccharides}

Hydrolysis of IDF and SDF was performed according to three different methods. 
Samples for GLC were hydrolysed with TFA, according to the principles of Albersheim et al. (1967). TFA $(0.2 \mathrm{ml} ; 2.0 \mathrm{M})$ was added to $10 \mathrm{mg}$ of isolated DF together with $1 \mathrm{mg}$ myoinositol, serving as internal standard. Hydrolysis was performed in a sealed tube at $121^{\circ} \mathrm{C}$ for $1 \mathrm{~h}$. TFA was removed from the hydrolysate by evaporation to dryness.

GLC analysis was performed as described elsewhere (Bjergegaard et al., 1995, 1997b).

Samples for HPLC $(70 \mathrm{mg})$ were boiled under reflux in $1.0 \mathrm{M} \mathrm{H}_{2} \mathrm{SO}_{4}(5 \mathrm{ml})$ for $16 \mathrm{~h}$. After cooling, the hydrolysate was centrifuged for $3 \mathrm{~min}(3000 \mathrm{~g})$ and the supernatant collected. Washing of the sediment with water $(1 \mathrm{ml})$ was performed 3 times, with recentrifugation and collection of supernatant after each washing step. The mixed hydrolysate was neutralised with a saturated $\mathrm{Ba}(\mathrm{OH})_{2}$ solution and centrifuged to removed precipitated $\mathrm{BaSO}_{4}$. The final volume of the neutralised supernatant was adjusted to $40 \mathrm{ml}$ and $10 \mathrm{ml}$ hereof was evaporated to dryness prior to further purification.

The hydrolysates were purified on reversed phase C-18 HPLC material (Bondapak C-18; $75 \mu \mathrm{M}$, Waters Associates) packed as $100 \mu \mathrm{l}$ of a material: methanol suspension (1:1) into glass wool containing pipette tips. The methanol was washed out gradually, increasing the proportion of water in the watermethanol solutions used for washing. About $200 \mu \mathrm{l}$ sample (redissolved in $1 \mathrm{ml}$ water) was transferred to the column, and the effluent was discarded to avoid dilution. Sample $(100 \mu 1)$ was loaded, and the effluent collected into HPLC vials.

Samples for HPCE were hydrolysed according to the method of Englyst and Cummings (1988). $\mathrm{H}_{2} \mathrm{SO}_{4}(1 \mathrm{ml} ; 12.0 \mathrm{M})$ was added to $100 \mathrm{mg}$ of isolated DF, mixed, and left for $1 \mathrm{~h}$ at $35^{\circ} \mathrm{C}$ in a shaking waterbath. In addition, manual shaking was performed after $30 \mathrm{~min}$. Water $(11 \mathrm{ml})$ was added, and the sample was boiled under reflux for $2 \mathrm{~h}$ with occasional mixing. The resulting hydrolysate was treated as described for the HPLC samples (vide infra). The neutralized supernatant was made up to a known volume (about $60 \mathrm{ml}$ ), and $15 \mathrm{ml}$ hereof was evaporated to dryness.

Purification prior to HPCE analysis was performed according to the principles of Bjerg et al. (1984). A strongly acidic cation exchanger (Dowex $50 \mathrm{w} \times 8 ; 200-400$ mesh $\left(\mathrm{H}^{+}\right)$) was connected to a strongly basic anion exchanger (Dowex $1 \times 8 ; 200-400$ mesh $\left(\mathrm{OH}^{-}\right)$). Ion exchange material:water suspension $(500 \mu \mathrm{l} ; 1: 1)$ were packed into tubes ( $1 \mathrm{ml}$ ) with outlet discs of silica material, and placed in a vacuum manifold (Supelco Inc., Pennsylvania, USA). The columns were washed with minimum $10 \mathrm{ml}$ water. Samples $(500 \mu \mathrm{l}$ of sample redissolved in $1 \mathrm{ml}$ water ) were transferred to the upper column (cation exchanger) and allowed to pass into the material of the connected columns. Elution was performed with $15 \mathrm{ml}$ water. The effluent was evaporated to dryness in a rotation evaporator, redissolved in $500 \mu \mathrm{l}$ or $1000 \mu \mathrm{l}$ water and used for HPCE analysis. 
HPLC and HPCE analyses were performed as described elsewhere (Frias et al., 1996; Bjergegaard et al., 1997b).

\section{Electrophoresis}

SDS-PAGE and IEF were performed as described in Bjergegaard et al. (1997b).

\section{RESULTS AND DISCUSSION}

\section{Corrections for protein and ash}

Filtration did not constitute any problem in method $\mathrm{I}$, whereas the omission of celite in method II prolonged the time for filtration of IDF. All samples were, however, possible to filtrate within 2-3 h. The level of IDF and SDF (uncorrected values), obtained by method I and II, respectively, are shown in Table 2 for some of the samples.

TABLE 2

Uncorrected level of IDF and SDF in selected pea and rape seed samples given as mean values (double determination). The figures in parenthesis are relative standard deviations, $\%$

\begin{tabular}{lccccc}
\hline \multirow{2}{*}{ Sample } & \multicolumn{2}{c}{ IDF } & & \multicolumn{2}{c}{ SDF } \\
\cline { 2 - 3 } \cline { 6 - 6 } \cline { 5 - 6 } & Method I & $\begin{array}{l}\text { Method II } \\
\text { \% of DM }\end{array}$ & & Method I & $\begin{array}{l}\text { Method II } \\
\text { \% of DM }\end{array}$ \\
\hline BOII & $17.5(0.6)$ & $15.7(10.6)$ & & $9.4(5.7)$ & $25.4(0.1)$ \\
PHU & $84.5(1.1)$ & $83.9(1.7)$ & & $15.2(9.4)$ & $27.7(3.4)$ \\
CER & $30.2(9.6)$ & $36.0(1.7)$ & & $9.4(1.2)$ & $14.8(7.4)$ \\
MRSW & $23.5(7.6)$ & $36.7(6.3)$ & & $10.6(23.0)$ & $17.7(12.8)$ \\
PRM & $25.6(0.3)$ & $30.4(0.8)$ & & $9.5(4.2)$ & $21.4(3.9)$ \\
LIPRO & $22.9(2.1)$ & $23.8(3.2)$ & & $7.3(2.8)$ & - \\
\hline
\end{tabular}

Method II gave considerably higher uncorrected SDF levels, compared to the results obtained using the method $I$ including traditional filtration and precipitation steps. For IDF, slightly higher values were seen only for the rape seed samples.

The calculated contents of protein and ash in the residues are shown in Table 3. The protein level in SDF was found to be considerably higher with method II, compared to method I, whereas the protein level in IDF was comparable in size for the two methods. Ash was generally not detected in IDF. This was also true for SDF determined by method II, whereas ash constituted up to $50 \%$ of the 
TABLE 3

The content of protein (P) and ash (A) in the residues from a double determination (1 and 2), \%

\begin{tabular}{|c|c|c|c|c|c|c|c|c|c|}
\hline \multirow{2}{*}{\multicolumn{2}{|c|}{ Sample }} & \multicolumn{4}{|c|}{ Method I } & \multicolumn{4}{|c|}{ Method II } \\
\hline & & \multicolumn{2}{|c|}{1} & \multicolumn{2}{|c|}{2} & \multicolumn{2}{|c|}{1} & \multicolumn{2}{|c|}{2} \\
\hline & & $\mathrm{P}$ & A & $\mathrm{P}$ & A & $\mathrm{P}$ & A & $P$ & $\mathrm{~A}$ \\
\hline $\mathrm{BOH}$ & IDF & 18.8 & 0.0 & 18.8 & 0.0 & 10.3 & 0.0 & 13.7 & 0.0 \\
\hline PHU & IDF & 2.0 & 0.0 & 1.9 & 0.0 & 1.5 & 0.0 & 1.5 & 0.0 \\
\hline CER & IDF & 18.9 & 0.0 & 17.2 & 3.4 & 16.4 & 0.0 & 14.5 & 0.0 \\
\hline MRSW & IDF & 22.7 & 0.0 & 24.6 & 0.0 & 17.6 & 0.0 & 19.3 & 0.0 \\
\hline PRM & IDF & 50.0 & 0.0 & 50.8 & 0.0 & 48.2 & 0.0 & 51.6 & 0.0 \\
\hline LIPRO & IDF & - & - & - & - & 17.0 & 1.2 & 19.3 & 0.0 \\
\hline $\mathrm{BOH}$ & SDF & 17.7 & 26.6 & 19.0 & 21.4 & 30.8 & 0.0 & 31.8 & 0.0 \\
\hline PHU & SDF & 8.9 & 30.9 & 9.9 & 22.9 & 20.9 & 0.0 & 25.2 & 0.0 \\
\hline CER & SDF & 11.5 & 47.8 & 11.7 & 47.2 & 36.4 & 0.0 & 39.7 & 0.0 \\
\hline MRSW & SDF & 14.4 & 32.9 & 10.8 & 49.8 & 36.7 & 0.0 & 39.3 & 0.0 \\
\hline PRM & SDF & 11.7 & 47.1 & 12.5 & 43.6 & 46.7 & 0.0 & 50.0 & 0.0 \\
\hline LIPRO & SDF & - & - & - & - & 39.7 & 0.0 & 42.3 & 0.0 \\
\hline
\end{tabular}

residues, when method I was used, and considerable variation was seen for these ash content determinations.

The level of DF obtained after correction for ash and protein in the residues is shown in Table 4. RSD values for SDF determination by method II were found to be high owing to the high correction values for proteins, whereas for IDF, the RSD values ranged from 0.1 to $16.1 \%$. The level of IDF and SDF for rape seed

TABLE 4 Corrected levels of IDF and SDF in selected pea and rape seed samples given as mean values (double determination). The figures in parenthesis are relative standard deviations, $\%$

\begin{tabular}{lccc}
\hline & Sample & \multicolumn{2}{c}{ Method } \\
\cline { 3 - 4 } & & I & $\begin{array}{c}\text { II } \\
\% \text { of DM }\end{array}$ \\
\cline { 3 - 4 } & & & $12.4(16.4)$ \\
BOH & IDF & $13.8(1.3)$ & $79.9(0.6)$ \\
PHU & IDF & $81.6(1.4)$ & $29.1(2.0)$ \\
CER & IDF & $22.4(8.8)$ & $28.2(5.3)$ \\
MRSW & IDF & $18.7(8.5)$ & $13.8(1.0)$ \\
PRM & IDF & $12.3(0.2)$ & $8.2(7.0)$ \\
BOH & SDF & $3.6(1.1)$ & $9.8(13.6)$ \\
PHU & SDF & $7.9(2.0)$ & $2.8(32.0)$ \\
CER & SDF & $2.7(0.7)$ & $3.4(31.4)$ \\
MRSW & SDF & $3.4(3.5)$ & $3.0(18.1)$ \\
PRM & SDF & $2.6(0.1)$ & \\
\hline
\end{tabular}


samples varied, dependent on the method used for calculation/determination. The level of IDF in the pea samples varied only little within double determinations and was also found relatively constant between the different methods.

The enzymatic gravimetric methods for determination of DF have evolved to their present state due to a comprehensive work within the last 10-15 years. The physiological approach of the methods has often been criticized for leading to a residue, which exact composition in outline is unknown to the analyst, and which contains different components in addition to the traditional DF constituents (NSP and lignins) (Bjergegaard et al., 1997a). This is, however, a question of definition, and should not be blamed the methods. Anyhow, a clarification regarding the correction for protein is needed within the nearest future. Concerning the ash correction, being complicated by ash bound water, the newest modification to the $\Lambda \mathrm{O} \Lambda \mathrm{C}$ procedure by Lee et al. (1992) seems to have reduced the problem by decreasing co-precipitation of buffer-salts. However, it is a question whether this modification is desirable from a physiological point of view. Rather, new methods for recovering of SDF, without contemporary recovering of ash, should be developed, and in this connection attention should be given to possible variation in the SDF level obtained according to different analytical principles. An evaluation of the type of polymers recovered as SDF by dialysis but excluded by the precipitation procedure should thus be performed as a first step in order to decide a possible inclusion of these polymers in the SDF fraction. Whether SDF then have to be determined directly or by difference calculation should depend on the precision of the actual method.

The procedure used for correction of results has been somewhat overlooked in the enzymatic gravimetric methods. In the present study, it has been shown, that the way of calculating the ash and protein content from the same set of data affected the precision of the methods, although the mean values remained within the same range. From an analytical point of view, correction for ash and protein in a residue should not be performed on the basis of results from analyses of another residue, as is the common procedure at present.

\section{Hydrolysis of polysaccharides}

Results obtained by analyses for individual sugars reflect especially the methods of polysaccharide hydrolysis. The procedures used for hydrolysis prior to GLC give an underestimation of glucose from polysaccharides as cellulose which only is slightly soluble in the solvent system used for hydrolysis. The techniques described by Englyst and Cummings (1988) which were used prior to HPCE give higher results for glucose from such slightly soluble $\beta$-glucans, but this system creates problems concerning the stability of other carbohydrates. 
TABLE 5

Relative proportion (\%) of monosaccharides in DF isolated from rape seed and peas. Determination of individual monosaccharides was performed by GLC (double determination, mean values given). Figures in parenthesis are standard deviations. \%

\begin{tabular}{|c|c|c|c|c|c|c|c|}
\hline \multicolumn{2}{|c|}{ Sample } & Fucose & Mannose & Galactose & Arabinose & Xylose & Glucose \\
\hline & & \multicolumn{6}{|c|}{ relative proportion, $\%$} \\
\hline \multirow[t]{2}{*}{ SOL } & IDF & $1.2(0.11)$ & $1.2(0.60)$ & $6.6(0.06)$ & $25.9(2.13)$ & $10.9(1.55)$ & $54.1(4.45)$ \\
\hline & SDF & - & - & - & - & - & - \\
\hline \multirow[t]{2}{*}{ KEL } & IDF & $1.5(0.11)$ & $0.8(1.06)$ & $10.7(0.12)$ & $35.0(0.02)$ & $14.8(1.53)$ & $37.3(0.50)$ \\
\hline & SDF & $2.5(0.02)$ & $2.4(0.11)$ & $41.2(0.15)$ & $5.4(0.30)$ & $1.5(0.19)$ & $47.0(0.26)$ \\
\hline \multirow[t]{2}{*}{$\mathrm{BOH}$} & IDF & $0.9(0.03)$ & $0.5(0.01)$ & $7.9(0.24)$ & $19.9(0.12)$ & $11.4(1.09)$ & $59.5(1.47)$ \\
\hline & SDF & $1.6(0.16)$ & $1.5(0.02)$ & $18.9(0.70)$ & $3.2(0.13)$ & $0.7(0.08)$ & $74.2(0.32)$ \\
\hline \multirow[t]{2}{*}{$\mathrm{BOH}$} & IDF & $1.0(0.02)$ & $0.3(0.43)$ & $12.7(0.59)$ & $28.5(0.09)$ & $11.1(0.66)$ & $46.4(3.23)$ \\
\hline & SDF & $1.7(0.10)$ & $1.4(0.02)$ & $16.8(0.45)$ & $3.6(0.08)$ & $0.6(0.02)$ & $75.8(0.44)$ \\
\hline \multirow[t]{2}{*}{$\mathrm{BOII}_{2}^{2}$} & IDF & $1.1(0.16)$ & $5.2(0.03)$ & $9.5(1.12)$ & $29.3(1.20)$ & $11.0(2.06)$ & $43.9(0.07)$ \\
\hline & SDF & $1.5(0.04)$ & $1.4(0.03)$ & $17.4(0.08)$ & $4.5(0.04)$ & $0.7(0.02)$ & $74.4(0.14)$ \\
\hline \multirow[t]{2}{*}{ PHU } & IDF & $2.1(0.05)$ & trace & $7.1(1.10)$ & $17.4(4.20)$ & $60.5(3.06)$ & $12.9(0.00)$ \\
\hline & SDF & $5.5(0.05)$ & $3.9(0.15)$ & $5.5(0.70)$ & $50.9(0.81)$ & $20.9(0.02)$ & $13.2(0.01)$ \\
\hline \multirow[t]{2}{*}{ MRS } & IDF & $3.3(0.04)$ & $2.4(3.38)$ & $25.1(1.08)$ & $33.7(1.25)$ & $15.7(0.48)$ & $19.8(0.52)$ \\
\hline & SDF & $3.5(0.25)$ & $5.7(2.17)$ & $22.9(0.79)$ & $55.6(1.42)$ & $6.3(0.01)$ & $6.0(0.20)$ \\
\hline \multirow[t]{2}{*}{ NRS } & IDF & $3.5(0.06)$ & $2.2(0.14)$ & $22.4(1.02)$ & $39.6(1.83)$ & $18.3(0.88)$ & $14.1(0.01)$ \\
\hline & SDF & $6.5(0.48)$ & $8.8(3.00)$ & $26.0(0.40)$ & $40.5(1.63)$ & $8.3(1.82)$ & $10.0(0.53)$ \\
\hline \multirow[t]{2}{*}{ PRM } & IDF & $4.1(0.17)$ & $12.6(2.45)$ & $31.5(0.89)$ & $17.4(0.78)$ & $13.2(0.54)$ & $21.1(0.07)$ \\
\hline & SDF & $6.2(0.07)$ & $11.6(0.59)$ & $38.4(0.51)$ & $22.3(0.03)$ & $13.3(0.04)$ & $8.2(0.02)$ \\
\hline \multirow[t]{2}{*}{$\mathrm{NRH}$} & IDF & $3.3 .(0.83)$ & $2.7(0.09)$ & $33.3(6.18)$ & $39.4(3.70)$ & $10.7(0.56)$ & $10.7(1.00)$ \\
\hline & SDF & $7.5(0.23)$ & $5.0(0.28)$ & $27.7(0.73)$ & $37.4(0.39)$ & $12.4(0.55)$ & $10.0(0.16)$ \\
\hline
\end{tabular}

Table 5 shows results from GLC determination of individual monosaccharides in hydrolysates from IDF and SDF.

The GLC analysis (Table 5) demonstrated a low content of fucose and mannose in pea DF, the level being highest for PHU SDF (9.4\%). The level of glucose found by GLC was low, especially for IDF, compared to the data obtained by HPLC, and consequently, the apparent proportion of the other monosaccharides increased. Apart from small deviations, the overall trend for IDF was, however, on the whole similar in GLC and HPLC. For SDF, arabinose was demonstrated in the intact seed samples (3.2-5.4\%). Otherwise, the GLC data corresponded well to the HPLC results, except for PHU, which appeared shown to have a completely different and more varied composition when analyzed by GLC. 
The monomeric composition of rape seed DF was shown to be different from that of pea DF (Table 5). In rape seed, fucose and mannose were present in higher levels, whereas the glucose content in general was a factor 2-7 lower, the reduction being greatest in the SDF fraction. The relative proportion of glucose in DF from rape seed and pea hulls was, however, very similar. The quantitatively dominating sugars in rape seed DF were galactose and arabinose, the sum constituting $49-73 \%$ and $61-79 \%$ of IDF and SDF, respectively. Generally, the level of arabinose was highest, apart from in PRM, being dominated by galactose.

\section{Fractionation of dietary fibres}

Studies of the plant cell wall matrix polysaccharides comprise certain difficulties as emphasized by Brett and Waldron (1990). The general experimental approach include purification of the plant cell wall followed by sequential extraction (fractionation) and physical/chemical studies of the extracted material. The two main problems in connection with fractionation are 1 . that a certain number of bonds must be broken in order to extract components from the cell wall, leading to incorrect conclusions about the chemistry of DF polysaccharides and 2. that the extraction of components may result in only partial recovery of a particular type of polysaccharide, and hereby lead to some discrepancy between the classification of polysaccharides, based on solubility properties and chemical composition, respectively.

Evaluation of the data oblained from fractionation of IDF and SDF from rape seed and peas, respectively, showed a varying and very complex picture for the relationship of PEC, HEM, CEL, and LIG, depending not only on the DF source but also on the actual calculation mode (Table 6).

The difference values obtained as Dif. (Table 6) are figures where the weight of a fraction is based on disappeared material. Although the preparation of plant material prior to fractionation has comprised an isolation of IDF and SDF, the Dif. values may cover up compounds not generally included in the DF fraction. An example is the occurrence of co-precipitated buffer salts in SDF, and this illustrates very well the problem with the enzymatic gravimetric method when used without dialysis (vide supra). Comparison of the weight of fractions obtained as Dif. and Abs. (Table 6) shows that Dif. values were a factor 3.1-9.5 (5.2 in average) higher for non-dialysed SDF, whereas the corresponding factor for SDF dialysed prior to the fractionation was 1.5-2.2 (1.9 in average). This emphasize, that a part of "pectic material" extracted from SDF by water actually consist of ash. 
TABLE 6

Proportion between pectic material, hemicelluloses, cellulose, and lignins in DF isolated from rape seed and peas. Dif., $A$ bs. and Thy values are obtained by the procedure described in the text. SDF" from MRS. NRS, PRM and NRH were dialysed prior to fractionation, $\%$

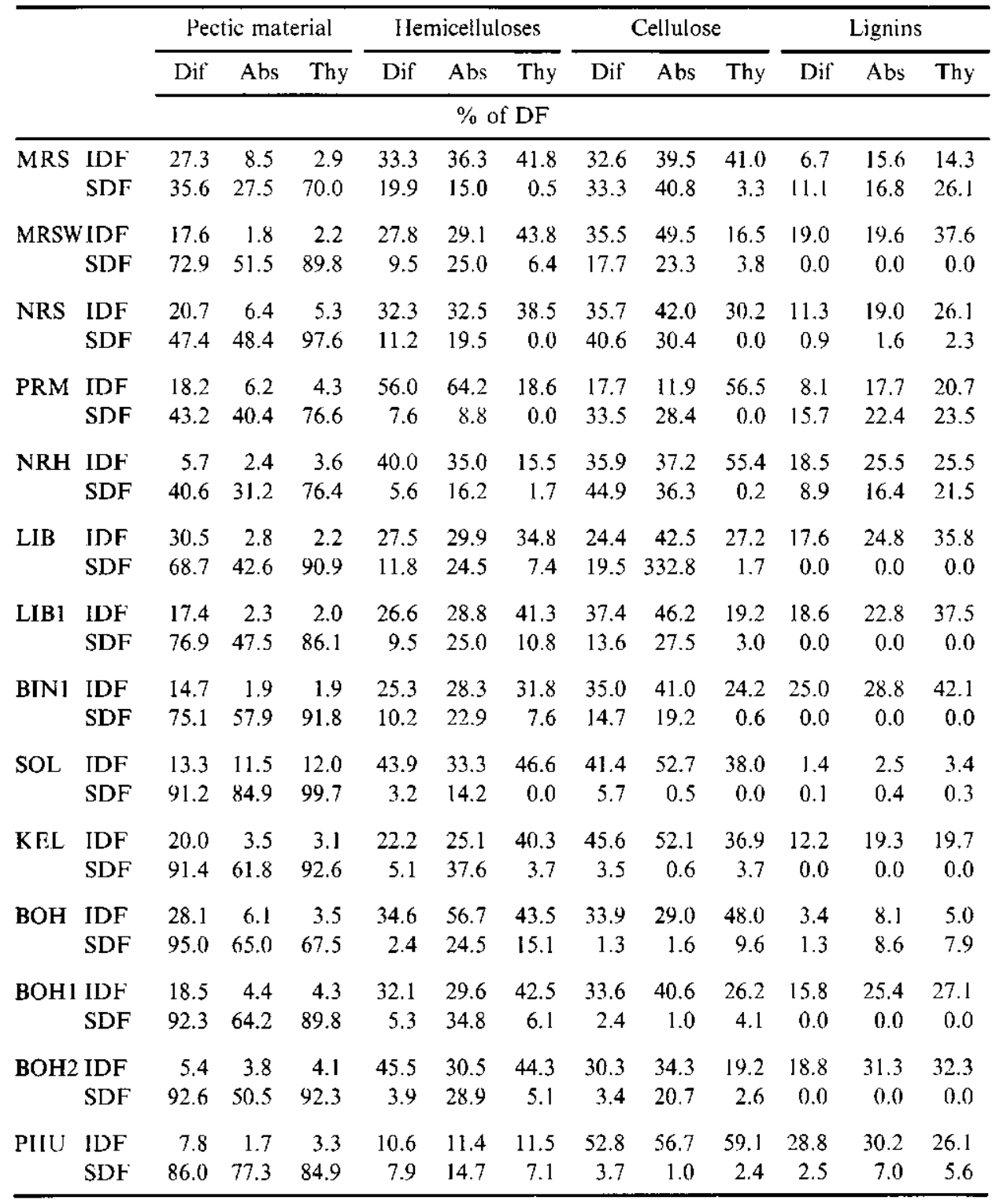

Dif. $=$ The weight difference between starting matcrial and dried sediment after corresponding extraction. Abs. $=$ The weight of the freeze dried supernatants. Thy $=$ results from Thymol- $\mathrm{H}_{2} \mathrm{SO}_{4}$ analysis. 


\section{Non-carbohydrate content in fractionated $D F$}

The absorption at $280 \mathrm{~nm}$ can in part for dialysed samples be considered as a relative measure for protein (Table 7), whereas low molecular weight compounds are removed by dialysis. As seen, the values arc highest for the non-dialysed PEC fraction in SDF and for the non-dialysed HEM fraction in IDF (Tables 7 and 8). This trend was common for rape seed and peas, however, the $280 \mathrm{~nm}$ absorption for rape seed IDF was in average a factor 5 higher than for pea IDF. A considerably higher absorption in IDF compared to SDF was also revealed from the sum of absorptions. For peas, this difference constituted a factor 2-5, whereas in rape seed, the corresponding factor was 4-15.

The absorption level within the various fractions in the different pea samples generally showed limited variation, with the exception of PHU IDF, apparently having a very high protein content in the CEL fraction. The presentation of data

TABLE 7

Content of protein in pectic material, hemicelluloses, and cellulose (DM basis) from pca IDF and SDF. The maximum value within the individual DF sources are shown in italics bold. The figures in percentage express the amount of $U V$ absorbent material retained after dialysis of the supernatants. b.d. = before dialysis; a.d. = after dialysis; n.d. = non-dialysed. Missing observations are marked by "-". Data are relative values, denoted mmol based on use of $\varepsilon=1500 \mathrm{M}^{-1}$ for protein in $\mathrm{E}=\varepsilon \cdot \mathrm{c} \cdot 1$

\begin{tabular}{|c|c|c|c|c|c|c|c|c|c|}
\hline \multirow{3}{*}{\multicolumn{2}{|c|}{ Sample }} & \multicolumn{8}{|c|}{ Protein content, $\mathrm{mmol} / \mathrm{g}$ isolated DF } \\
\hline & & \multicolumn{3}{|c|}{ Pectic material } & \multicolumn{3}{|c|}{ Hemicelluloses } & \multirow{2}{*}{$\frac{\text { Cellulose }}{\text { n.d.: }}$} & \multirow[t]{2}{*}{ SUM } \\
\hline & & b.d.' & a.d. ${ }^{2}$ & $\%$ & b.d.' & a.d. & $\%$ & & \\
\hline \multirow[t]{2}{*}{ SOL } & IDF & 0.14 & 0.05 & 35.0 & 0.52 & 0.08 & 16.3 & 0.09 & 0.74 \\
\hline & SDF & 0.33 & 0.21 & 63.9 & 0.04 & 0.01 & 11.6 & 0.01 & 0.38 \\
\hline \multirow[t]{2}{*}{ KEL } & IDF & 0.12 & 0.03 & 25.2 & 0.51 & 0.07 & 14.3 & 0.14 & 0.77 \\
\hline & SDF & 0.34 & 0.13 & 38.2 & 0.02 & 0.01 & 31.8 & 0.00 & 0.36 \\
\hline \multirow[t]{2}{*}{$\mathrm{BOH}$} & IDF & - & 0.02 & - & 0.38 & 0.05 & 14.1 & 0.18 & $0.59 *$ \\
\hline & SDF & - & 0.09 & - & 0.02 & 0.00 & 16.7 & 0.00 & $0.11^{*}$ \\
\hline \multirow[t]{2}{*}{ BOHI } & IDF & 0.11 & 0.03 & 25.7 & 0.46 & 0.08 & 17.2 & 0.08 & 0.65 \\
\hline & SDF & 0.29 & 0.11 & 37.5 & 0.02 & 0.01 & 31.8 & 0.01 & 0.32 \\
\hline \multirow[t]{2}{*}{$\mathrm{BOH} 2$} & $\mathrm{IDF}$ & 0.10 & 0.02 & 20.2 & 0.53 & 0.10 & 19.5 & 0.08 & 0.71 \\
\hline & SDF & 0.30 & 0.11 & 37.5 & 0.03 & 0.01 & 18.2 & 0.00 & 0.33 \\
\hline \multirow[t]{2}{*}{ PHU } & IDF & - & 0.01 & - & 0.33 & 0.05 & 15.0 & 0.41 & $0.76^{*}$ \\
\hline & SDF & - & 0.13 & - & 0.05 & 0.01 & 12.5 & 0.01 & $0.18^{*}$ \\
\hline
\end{tabular}

\footnotetext{
${ }^{1}$ values used for calculation of the sum

${ }^{2}$ values used for calculation of the sum if missing observations before dialysis

* sum calculated partly on the basis of values from 2
} 
TABLE 8 Content of protein in pectic material, hemicelluloses, and ccllulose (DM basis) from rape sced IDF and SDF. Comments and foolnotes as in Table 7

\begin{tabular}{|c|c|c|c|c|c|c|c|c|c|}
\hline & & & & Protei & ntent, & $\mathrm{ol} / \mathrm{g}$ is & d DF & & \\
\hline Sam & & & ic mat & & & icellul & & Cellulose & SUM \\
\hline & & b.d.' & a.d.? & $\%$ & b.d. ${ }^{\prime}$ & a.d. & $\%$ & n.d. ${ }^{\prime}$ & \\
\hline MRS & IDF & 0.20 & 0.04 & 21.8 & 1.08 & 0.20 & 18.0 & 0.05 & 1.34 \\
\hline & SDF & 0.24 & 0.15 & 63.6 & 0.03 & 0.04 & - & 0.03 & 0.30 \\
\hline MRSW & IDF & 0.09 & 0.02 & 24.9 & 2.94 & 0.46 & 15.7 & 0.04 & 3.07 \\
\hline & SDF & 0.18 & 0.13 & 72.8 & 0.08 & 0.01 & 14.7 & 0.01 & 0.28 \\
\hline NRS & IDF & 0.20 & 0.05 & 25.2 & 2.52 & 0.59 & 26.2 & 0.07 & 2.51 \\
\hline & SDF & 0.40 & 0.30 & 75.8 & 0.02 & 0.07 & 29.7 & 0.02 & 0.44 \\
\hline PRM & IDF & 0.20 & 0.07 & 37.6 & 1.48 & 0.25 & 16.6 & 0.03 & 1.71 \\
\hline & SDF & 0.33 & 0.29 & 88.5 & 0.06 & 0.01 & 9.8 & 0.02 & 0.40 \\
\hline $\mathrm{NRH}$ & IDF & 0.09 & 0.03 & 33.8 & 4.82 & 1.39 & 28.7 & 0.07 & 4.97 \\
\hline & SDF & 0.21 & 0.12 & 57.5 & 0.10 & 0.02 & 14.7 & 0.02 & 0.33 \\
\hline LIB & IDF & 0.15 & 0.03 & 22.0 & 2.06 & 0.46 & 22.1 & 0.05 & 2.26 \\
\hline & SDF & 0.19 & 0.13 & 70.4 & 0.10 & 0.02 & 15.9 & 0.01 & 0.30 \\
\hline LIB 1 & IDF & 0.13 & 0.03 & 26.4 & 2.40 & 0.59 & 24.5 & 0.05 & 2.58 \\
\hline & SDF & 0.30 & 0.22 & 74.3 & 0.14 & 0.01 & 7.9 & 0.01 & 0.45 \\
\hline BIN1 & IDF & 0.11 & 0.04 & 32.2 & 2.69 & 0.59 & 21.9 & 0.05 & 2.85 \\
\hline & SDF & 0.30 & 0.25 & 82.5 & 0.10 & 0.01 & 13.3 & 0.01 & 0.41 \\
\hline
\end{tabular}

as $\mathrm{mmol} / \mathrm{g}$ isolated DF do, however, not take into account, that the actual amount of CEL in IDF from PHU was about two times higher compared to the other pea samples, making the difference per $\mathrm{g} /$ cellulose less marked. This has to be taken into consideration in evaluation of the data.

Differences in the absolute amount of material in the various rape seed fractions (Table 8) did, however, only explain a minor part of the variations obtained in absorption here. The HEM fraction of NRH IDF differed in having an extremely high absorption at $280 \mathrm{~nm}$, and this indication of a high protein content in the HEM fraction was confirmed by data from isoelectric focusing of the dialysed freeze dried material.

The absorption retained after dialysis was calculated for PEC and HEM supernatants, respectively, and gives an idea of 1. the type (size) of UV absorbent material and 2. its association to the other DF components in the fractions. About $75 \%$ of the UV absorbent compounds disappeared from the PEC supernatant of IDF after dialysis, indicating, that the main part of this material was LMW compounds present in free solution or loosely adsorbed to com- 
ponents in this fraction. Note that part of these compounds not necessarily have been associated to pectic material originally, but as well could have been extracted from other DF components to the PEC supernatant by the $2 \mathrm{~h}$ water treatment. In rape seed SDF, the main part of the UV absorbent material was retained $(60-90 \%)$, whereas in pea, the corresponding figures varied from $40-60 \%$. This difference are not alone brought about by dialysis of rape seed SDF prior to fractionation, as also non-dialysed rape seed samples showed a higher retainment percent.

The UV absorbent material in the HEM supernatants must originally have been present as strongly adsorbed or covalently bound components, as more readily extractable material are expected to occur in the PEC fraction as described above. $20 \%$ or less of the UV absorbent material was retained in the dialysed HEM supernatant of IDF as well as SDF, and this indicates, that the dominating association type for these compounds was alkali-labile, e.g. ester bonds. Actually, it is not possible to decide the origin of this ester bound material, which could be from the LIG or CEL fraction as well as from the HEM fraction. The possible presence of compounds of non-protein origin with absorption at $280 \mathrm{~nm}$ emphasize, that the calculated protein content is an arbitrary figure. So, the information from UV-VIS-spectra should preferably be used as a first hint of the occurrence of compounds of non-carbohydrate origin in the DF fraction. This has then to be followed up by further investigations of the compounds present. The occurrence of ester bound benzoic acid derivatives has been demonstrated in IDF from rape seed by use of HPCE (Bjergegaard et al., 1997b). Ether bound or carbon-carbon bound substituents will not be released by the alkali treatment.

The absorption at $320 \mathrm{~nm}$ (Tables 9 and 10) followed in outline the same pattern as described above for $280 \mathrm{~nm}$, however, the difference in the total sum of absorption between IDF and SDF was even more distinct (5-12 and 8-30 times higher for IDF in peas and rape seed, respectively).

Comparison of the sum of absorption at $320 \mathrm{~nm}$ of PHU and NRH IDF showed a 12 times higher absorption for rape seed hulls, whereas the difference for the whole seeds was less marked (4 times higher for rape seed). The very high absorption in the HEM fraction of NRH IDF may be partly mediated by the dark colour of the supernatant, probably caused by an oxidation of phenolic material associated to the hemicellulosic components. In general, the supernatants obtained after alkali-treatment of rape seed as well as pea samples were more or less coloured, indicating that the extraction under $\mathrm{N}_{2}$ was insufficient to avoid oxidative degradation completely. Neutralization with acetic acid reduced the colour slightly and the spectrophotometric measurements were performed on the $\mathrm{pH}$ adjusted samples. However, this procedure exclude contribution from UV absorbent compounds associated to hemicellulose $\mathrm{A}$. The presence of 
TABLE 9

Content of cinnamic acid derivatives in pectic material, hemicelluloses, and cellulose (DM basis) from pea IDF and SDF. The maximum value within the individual DF sources are shown in italics bold. The figures in percentage express the amount of UV absorbent material retained after dialysis of the supernatants. b.d. = before dialysis; a.d. = after dialysis; n.d. = non-dialysed. Missing observations are marked by "-". Data are relative values, denoted mmol, based on use of $\varepsilon=15000 \mathrm{M}^{-1}$ for cinnamic acid in $\mathrm{E}=\varepsilon \cdot \mathrm{c} \cdot \mathrm{l}$

\begin{tabular}{|c|c|c|c|c|c|c|c|c|c|}
\hline \multirow{3}{*}{\multicolumn{2}{|c|}{ Sample }} & \multicolumn{8}{|c|}{ Cinnamic acid content, $\mu \mathrm{mol} / \mathrm{g}$ isolated DF } \\
\hline & & \multicolumn{3}{|c|}{ Pectic material } & \multicolumn{3}{|c|}{ Hemicelluloses } & \multirow{2}{*}{$\frac{\text { Cellulose }}{\text { n.d.' }}$} & \multirow[t]{2}{*}{ SUM } \\
\hline & & b.d.' & a.d. ${ }^{2}$ & $\%$ & b.d. ${ }^{\prime}$ & a.d. & $\%$ & & \\
\hline \multirow[t]{2}{*}{ SOL } & IDF & 5.6 & 2.2 & 38.4 & 31.1 & 5.2 & 16.9 & 2.2 & 38.9 \\
\hline & SDF & 5.8 & 5.1 & 86.6 & 1.6 & 0.3 & 20.0 & 0.6 & 8.0 \\
\hline \multirow[t]{2}{*}{ KEL } & IDF & 2.6 & 1.1 & 41.7 & 29.8 & 3.8 & 12.9 & 4.0 & 36.4 \\
\hline & SDF & 3.7 & 2.0 & 54.4 & 0.3 & 0.1 & 51.9 & 0.1 & 4.0 \\
\hline \multirow[t]{2}{*}{ BOH } & IDF & - & 0.6 & - & 20.2 & 3.3 & 16.3 & 2.7 & $23.5^{*}$ \\
\hline & SDF & - & 1.6 & - & 0.3 & 0.1 & 33.3 & 0.0 & $1.9^{*}$ \\
\hline \multirow[t]{2}{*}{ ВOH 1} & IDF & 2.7 & 1.0 & 36.4 & 24.5 & 4.4 & 17.8 & 3.2 & 30.3 \\
\hline & SDF & 3.6 & 1.8 & 50.0 & 0.3 & 0.1 & 40.9 & 0.0 & 4.0 \\
\hline \multirow[t]{2}{*}{$\mathrm{BOH} 2$} & IDF & 2.3 & 0.7 & 28.2 & 29.8 & 6.1 & 20.4 & 2.3 & 34.5 \\
\hline & SDF & 4.4 & 2.1 & 48.7 & 1.1 & 0.2 & 13.0 & 0.1 & 5.6 \\
\hline \multirow[t]{2}{*}{ PHU } & IDF & - & 0.6 & - & 24.5 & 3.2 & 13.0 & 5.5 & $30.6^{*}$ \\
\hline & SDF & - & 3.5 & - & 1.1 & 1.9 & - & 0.1 & $4.7^{*}$ \\
\hline
\end{tabular}

cinnamic acid derivatives in isolated DF has been confirmed by use of HPCE-MECC (Bjergegaard et al., 1992, 1997b) and combined with the recently developed SFE technique (Buskov et al., 1997) this gives an efficient tool for determination of such DF associated compounds.

UV-VIS-spectroscopy resulted in useful information on the amount of DF associated material of non-carbohydrate origin in the fractions. Generally, the IDF fraction showed the highest absorption at $280 \mathrm{~nm}$ and $320 \mathrm{~nm}$, and the level was considerably higher for rape seed than for peas. The data showed, that especially the HEM fraction contained proteins and/or benzoic and cinnamic acid derivatives. However, this information has also been followed up by more specific methods in order to get a determination of the actual type and amount of compounds. SDS-PAGE and IEF of proteins and HPCE for proteins and LMW compounds associated to DF have been found to be suitable methods in this respect, as already demonstrated for phenolic carboxylic acids (Bjergegaard et al., 1992, 1997b), LMW carbohydrates (Arentoft et al., 1992; Frias et al., 1996) and various types of other LMW compounds as well as for proteins (Bjergegaard et al., 1997b). 
TABLE 10

Content of cinnamic acid derivatives in pectic material, hemicelluloses and cellulose (DM basis) from rapcsecd IDF and SDF. Comments and footnotes as in Table 9

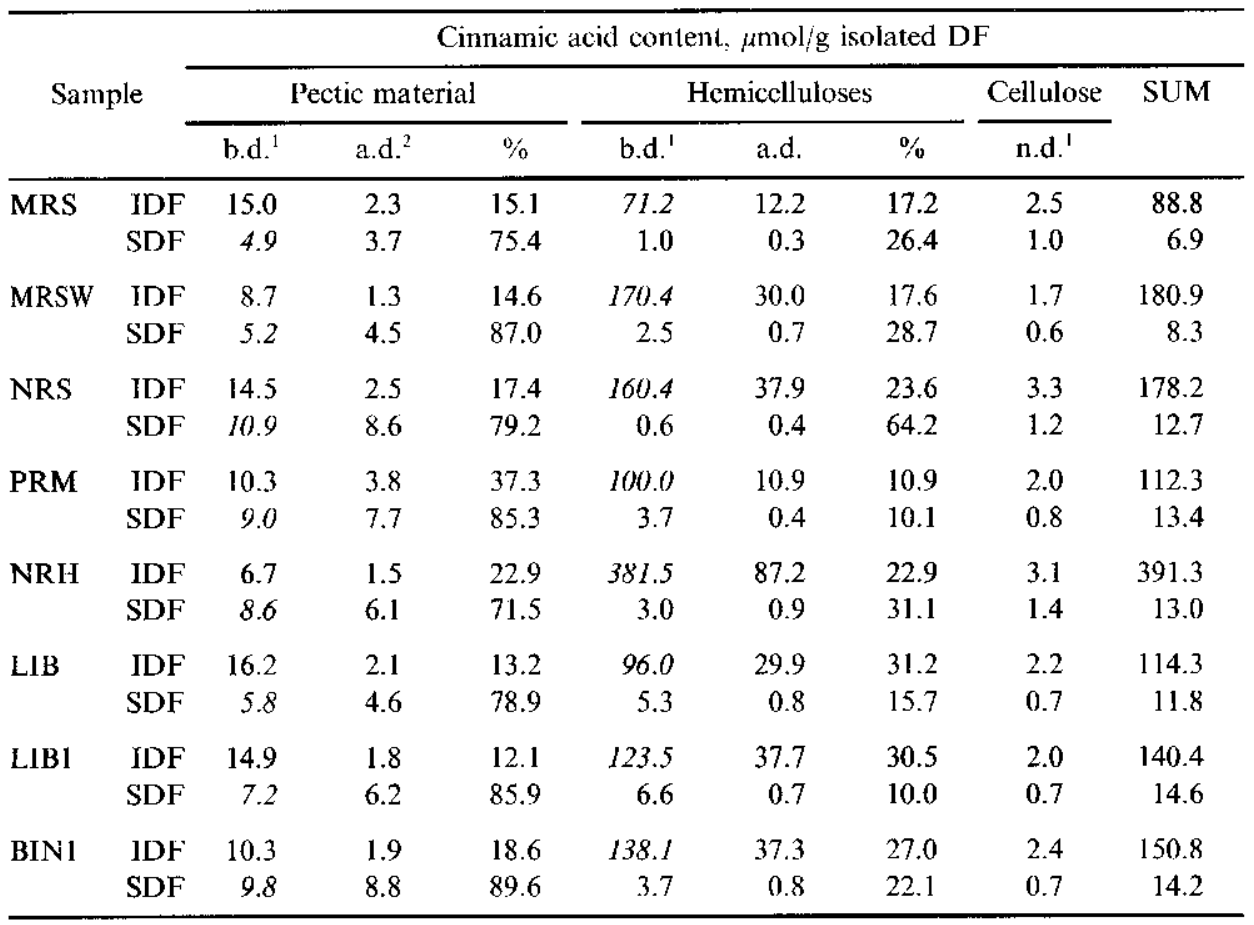

Chromatographic techniques with these new developments (Bjergegaard et al., 1997b) are well suited for analysis of DF including determination of the NSP monosaccharides composition as a first step, but also in respect to oligo- and polysaccharides as well as non-traditional DF components as LMW phenolics and oligosaccharides. Up till now, GLC and HPLC have been the techniques preferred for monosaccharide analysis, however, HPCE provides a good alternative. The enzymatic gravimetric methods for determining IDF, SDF and TDF are good starting points for chromatographic investigations and further fractionation studies, but are also valuable themselves.

\section{ACKNOWLEDGEMENTS}

The authors gratefully acknowledge financial support from EU, DGXII (DIPA-CT 93-0249) and from the Danish Ministry of Agriculture. 


\section{REFERENCES}

AOAC, 1965. Association of Official Analytical Chemists. Official Methods of Analysis. Washington D.C., p. 139

Albersheim P., Nevins D.J., English P.D., Karr A., 1967. A method for the analysis of sugars in plant cell-wall polysaccharides by gas-liquid chromatography. Carbohydr. Res. 5. 340-345

Arentoft A.M., Sørensen H., 1992. $\alpha$-Galactosides and dietary fibres in relation to pea quality; Methods of oligosaccharidc analysis. 1st European Conference on Grain Legumes, Angers (France), pp. 457-459

Asp N.G., 1990. Delimitation problems in definition and analysis of dietary fiber. In: I. Furda. C.J. Brine (Editors). New developments in dietary fiber - physiological, physicochemical, and analytical aspects. Plenum Press, New York/London, pp. 227-236

$\Lambda$ sp N.G., Johansson C.G., Hallmer H., Siljeström M., 1983. Rapid enzymatic assay of insoluble and soluble dictary fiber. J. Agric. Food Chem. 31, 476-482

Asp N.G., Björck I.. Hołrn J., Nyman M., Siljeström M., 1987. Enzyme resistant starch fractions and dietary fibre. Scand. J. Gastroenterol. 22, 29-32

Asp N.G., Furda I., Schweizer T.F., Prosky L., 1988. Dictary fiber definition and analysis. Amer. J. Clin. Nutr. 48, 688-690

Bagger C., Sørensen H. Sørensen J.C., 1996. High quality oil, protein and bioactive products, Food and non-food purpose based on biorcfining of cruciferous oilseed crops. Congress on plant protein for European Crops. Food and non-food application, Food and non-food application. Nantes (France)

Bjerg B., Olsen O., Rasmussen K.W., Sørensen H., 1984. New principles of ion-exchange techniques suitable to sample preparation and group separation of natural products prior to liquid chromatography. J. Liquid Chromatogr. 7, 691-707

Bjergegaard C., Michaelsen S., Sørensen H., 1992. Determination of phenolic carboxylic acids by micellar electrokinetic capillary chromatography. J. Chromatogr. A, 608, 403-411

Bjergegaard C., Ochodzki P., Rakowska M., Sørensen H., 1995. Studies on enzyme based fractionation, chemical composition and biological effects of dietary libres in rape seed (Brassica napus L.). I. Chemical composition of seeds and characteristics of soluble and insoluble dietary fibres of spring and winter type varieties of double low oilseed rapc. J. Anim. Fced Sci. 4, 127-138

Bjergegaard C., Sørensen II., Sørensen S., 1997a. Dietary fibres - important parts of high quality foods and feeds. J. Anim. Feed Sci. 6, 145-161

Bjergegaard C., Michaclsen S., Sørensen, H., Sørensen, S., 1997b. Chromatography and Capillary Electrophoresis in Food Analysis. The Royal Society of Chemistry, Cambridgc, UK (In press)

Brett C., Waldron K., 1990. Cell wall structure and the skeletal functions of the wall. In: Physiology and biochemistry of plant cell walls. Unwin Hyman, London, 194 pp.

Buskov S., Sørensen H., Sørensen J.C., Sørensen S., 1997. Extraction of oil from plant material with Supercritical carbon dioxidc. Polish J. Food Nutr. Sci. (In press)

Brett C., Waldron K., 1990. Physiology and biochemistry of plant cell walls. Union Hyman, London, $194 \mathrm{pp}$.

Dreher M.L., 1987. Conventional and unconventional dietary fiber components. In: Handbook of dietary fiber. An applied approach. Marcel Dekker Inc., Now York/Basel, pp. 17-49

Englyst H.N., Cummings J.H., 1988. Improved method for measurement of dietary fiber as non-starch polysaccharides in plant foods. J. Assoc. Off. Anal. Chem. 71, 808-814

Frias J., Price K.R., Fenwick G.R., Hedley C.L., Sørensen H., Vidal-Valverde C., 1996. Improved method for the analysis of $\alpha$-galactosides in pea secds by capillary zone electrophoresis. Comparison with high performance liquid chromatography triple-pulsed amperametric detection. J. Chromatogr. 719, 213-219 
Fry S.C., 1988. Wall polymers: extraction and fractionation. In: M. Wilkins (Editor). The growing plant cell wall: chemical and metabolic analysis. Longman Scientific and Technical, pp. 49-101

Furda I., 1981. Simultaneous analysis of soluble and insoluble dietary fiber. In: W.P.T. James, O. Theander (Editors). The analysis of dietary fiber in food. Marcel Dekker Inc., New York/Basel, pp. 163-172

Jensen S.K., Olsen H.S., Sørensen H., 1990. Aqueous enzymatic processing of rape seed for production of high quality products. In: F. Shahidi (Editor). Rapeseed/Canola: Production, chemistry, nutrition and processing technology, Van Nostrand Reinhold Publisher, New York, pp. 331-343

Lee S.C., Prosky L., DeVries J.W., 1992. Determination of total, soluble and insoluble dietary fiber in foods. Enzymatic-gravimetric method, MES-TRIS buffer: Collaborative study. J. Assoc. Off. Anal. Chem. Int. 75, 395-416

Olsen H.S., 1988. Aqueous enzymatic extraction of rape seed oil. Workshop on Agricultural Refineries. Bornholm, Denmark, 10 pp.

Prosky L., Asp N.G., Furda I., DeVries J.W., Schweizer T.F., Harland B.F., 1984. Determination of total dietary fiber in foods, food products and total diets: Interlaboratory study. J. Assoc. Off. Anal. Chem. 67, 1044-1052

Prosky L., Asp N.G., Furda I., DeVries J.W., Schweizer T.F., Harland B.F., 1985. Determination of total dietary fiber in foods and food products: Collaborative study. J. Assoc. Off. Anal. Chem. $68,677-679$

Prosky L., Asp N.G., Schweizer T.F., DeVries J.W., Furda I., 1988. Determination of insoluble, solublc and total dietary fiber in foods and food products: Interlaboratory study. J. Assoc. Off. Anal. Chem. 71,1017-1023

Prosky L., DeVries J.W., 1992a. Development of the association of official analytical chemists method for total, soluble and insoluble dietary fiber. In: Controlling dietary fiber in food products. Van Nostrand Reinhold, New York, pp. 47-90

Prosky L., DeVries J.W., 1992b. Regulations and marketing. In: Controlling dietary fiber in food products. Van Nostrand Rcinhold, New York, pp. 91-122.

Schweizer T.F., Würsch P., 1979. Analysis of dietary fibre. J. Sci. Food Agric. 30, 613-619

Selvendran R.R., Stevens B.J.H., O'Neill M.A., 1985. Developments in the isolation and analysis of cell walls from edible plants. In: C.T. Brett, J.R. Hillman (Editors). Biochemistry of plant cell walls. Cambridge University Press, Cambridge/London/New York/New Rochelle/Melbourne/Sydney, pp. 39-78

Southgate D.A.T., 1991. The measurement of unavailable carbohydrates: Structural polysaccharides and dietary fibre. In: Determination of food carbohydrates. Elsevier Applied Science, London/New York, pp. 73-92

Theander O., 1983. Advances in the chemical characterization and analytical determination of dietary fibre components. In: G.G. Birch, K.J. Parker (Editors). Dietary fibre. Applied Science Publisher, London/New York, pp. 77-93

Van Soest P.J., 1963. Use of detergents in the analysis of fibrous feeds. II. A rapid method for the determination of fiber and lignin. J. Assoc. Off. Anal. Chem. 46, 829-835

Van Soest, P.J., Wine R.H. 1967. Use of detergents in the analysis of fibrous feeds. IV. Determination of plant cell wall constituents. J. Assoc. Ofr. Anal. Chem. 50, 50-55 


\section{STRESZCZENIE}

Porównanic wlókna pokarmowego i związków towarzyszących DF w rzepaku i produktach jego frakcjonowania oraz DF grochu

Włókno pokarmowe (DF) - jego skład chemiczny, budowa, właściwości fizyko-chemiczne i dzialanie fizjologiczne są obecnie przedmiotem rosnącego zainteresowania. Postęp $w$ tych badaniach utrudniony jest przez brak uzgodnionej definicji pojęcia DF. W przedstawionych badaniach zastosowano fizjologicznic uzasadnioną metodę oznaczania ogólnej zawartości DF (TDF) jako sumy DF nicrozpuszczalnego (IDF) i rozpuszczalnego (SDF) do porównania DF różnych odmian oraz frakcji rzepaku i DF grochu.

Przeprowadzono szeroką charakterystykę DF rzepaku i grochu obejmującą w pierwszym etapie oznaczenie różnymi metodami składu obojętnych cukrów prostych. Ilość cukrów, zwłaszcza glukozy, zależała w dużym stopniu od metody hydrolizy wielocukrów. Skład frakcji wielocukrów różnił się w zależności od rodzaju materiału roślinnego. Różnorodność tę potwierdziły wyniki ckstrakcji i rozdziału DF pozwalające na wyodrębnienie czterech grup związków: pektyn, hemicelulory, celulozy i ligniny. Spektroskopia UV-VIS ekstraktów tych grup wykazała obecność związków nic będących węglowodanami. We frakcji hemicelulozy grochu, a zwlaszcza rzepaku, stwierdzono największą zawartość białek i fenoli, prawdopodobnie silnie adsorbowanych lub związanych kowalencyjnic. Częśś białkową frakcji DF analizowano następnic metodami biochemicznymi: chromatografii powinowactwa, clektroforezy z. zastosowaniem SDS i IEF. W DF rzepaku stwierdzono obecność myrozynazy. Równiez groch zawierał białko związane z DF, jednak jego zawartość była znacznie mniejsza niż w DF rzepaku. Opracowano metody wysoko wydajnej elek troforezy kapilarnej do oznaczania związków fenolowych jako składnika DF. Zastosowanje tych metod do analizy DF i jego frakcji pozwoliło na stwierdzenie obecności znacznych ilości białka i różnych związków o niskicj masie cząsteczkowej, zwlaszeza fenoli, jako składników powiązanych $z \mathrm{DF}$. 